\title{
Proteins and peptides in parotid saliva of irradiated patients compared to that of healthy controls using SELDI-TOF-MS
}

\author{
Alexa M. G. A. Laheij ${ }^{*}$, Coen N. Rasch², Bernd W. Brandt ${ }^{1}$, Johannes J. de Soet ${ }^{1}$, Raymond G. Schipper ${ }^{3}$, \\ Arnoud Loof ${ }^{4}$, Erika Silletti ${ }^{5}$ and Cor van Loveren ${ }^{1}$
}

\begin{abstract}
Background: Radiotherapy to the head and neck area damages the salivary glands. As a consequence hyposalivation may occur, but also the protein composition of saliva may be affected possibly compromising oral health. The aim of our study was to compare the relative abundance of proteins and peptides in parotid saliva of irradiated patients to that of healthy controls.

Methods: Using Lashley cups and citric acid, saliva from the parotid glands was collected from nine irradiated patients and ten healthy controls. The samples were analyzed with SELDI-TOF-MS using a NP20 and IMAC-30 chip in the molecular weight range of 1-30 kDa.

Results: On the NP20 chip 61 (out of 217) and on the IMAC-30 chip 32 (out of 218) peaks differed significantly in intensity between the saliva of the irradiated patients and healthy controls. $55 \%$ of the significant peaks showed higher intensity and $45 \%$ showed lower intensity in the saliva of irradiated patients. The peaks may represent, amongst others, the salivary proteins lysozyme, histatins, cystatin, protein S100 and PRP's.
\end{abstract}

Conclusions: Large differences were found in the relative abundance of a wide range of proteins and peptides in the parotid saliva of irradiated patients compared to healthy controls.

Keywords: Head and neck cancer, Saliva, Proteomics, Parotid gland, SELDI-TOF-MS

\section{Background}

Radiotherapy is often needed for the management of a tumor in the head and neck area. Usually radiotherapy involves the primary treatment of a tumor, but it can also be used additionally to surgery or as part of palliative care. The radiation-induced consequences for the healthy oral tissues can be divided into early and late effects. The early effects consist of damage to the oral mucosa, salivary glands and taste. Late effects comprise damage to the salivary glands, dentition, periodontium, bone, muscles and the joints $[1,2]$.

\footnotetext{
*Correspondence: a.laheij@acta.nl

${ }^{1}$ Department of Preventive Dentistry, Academic Centre for Dentistry Amsterdam, University of Amsterdam and VU University Amsterdam, Gustav Mahlerlaan 3004, 1081 LA Amsterdam, The Netherlands Full list of author information is available at the end of the article
}

Damage to the salivary glands leads to a rapid decrease in salivary flow after the start of radiotherapy [3]. Weeks after the start of radiotherapy, the flow rate gradually starts to recover and only after 5 years the mean parotid flow rate may return to baseline levels $[4,5]$. However, $21 \%$ of patients still suffered from a significantly lowered salivary flow 5 years after radiotherapy [5].

There are secondary effects related to changes in salivary flow and to changes in composition. Saliva is an important host defense mechanism helping to keep the oral cavity free of diseases like caries, gingivitis, periodontitis and infections as a result of antimicrobial, buffering and remineralizing capacities [6, 7]. There is a risk for radiation caries, a form of caries that develops very rapidly when salivary functions are disturbed and affects tooth surfaces that are normally resistant to the development of caries [8]. 
Also the changes in the composition of saliva imply that the salivary $\mathrm{pH}$ and buffer capacity, as a result of a lower bicarbonate concentration, are significantly lower compared to healthy controls $[9,10]$ and the concentrations of sodium, chloride, calcium, potassium, phosphate and magnesium in saliva have been changed [9-12]. The oral microflora also changes in composition. The increase of the acidogenic bacteria Streptococcus mutans and Lactobacillus species and the yeast Candida may be a further threat for dental health [13-16].

After radiotherapy the total protein concentration may increase [9-11]. For individual proteins, it was found that the concentration of acidic proline-rich proteins (PRP's), amylase, epidermal growth factor and MUC5B in the saliva of irradiated patients was lower than in healthy controls [9, 17-19], whereas the levels of lactoferrin, lysozyme, albumin, peroxidase, IgA, IgG and haptocorrin in saliva were elevated after irradiation [9-12, 18, 20]. When interpreting the changed concentrations of salivary proteins, it should be taken into account that the amount of salivary flow determines the total availability of these proteins in the oral cavity [10,21].

The salivary proteins studied in irradiated patients so far make up only a small proportion of the total amount of proteins and peptides in saliva [6, 22]. More knowledge on the changes in a wide range of salivary proteins and peptides could make it possible to screen patients for specific markers for the prediction of oral health, to monitor effects of treatment or preventive measures and to follow the composition over time.

Surface enhanced laser desorption/ionization time-offlight mass spectrometry (SELDI-TOF-MS) is a method for the proteomic analysis of saliva [23]. It is a high throughput method that produces protein/peptide profiles of biological samples in the range of about $1-30 \mathrm{kDa}$ $[24,25]$. This technique separates proteins and peptides using their chemical and physical characteristics. Upon laser desorption and ionization an accurate protein/peptide profile of the sample is generated. SELDI-TOF-MS was used in several clinical studies to discover biomarkers [26-30] in saliva and to examine proteomic profiles in the saliva of hematopoietic stem cell transplant patients [31].

Our hypothesis was that many more salivary proteins differ between irradiated patients and healthy controls than those that were studied before. We conducted a cross-sectional study in which we compared proteins and peptides in parotid saliva between healthy controls and patients that were irradiated in the head and neck area. The aim of our study was to make an inventory of the differences in the relative abundance of a wide range of proteins in the parotid saliva of irradiated patients and healthy controls using SELDI-TOF-MS.

\section{Methods}

\section{Subjects}

Nine patients ( 5 females, 4 males) who had received radiotherapy for a tumor in the head and neck area participated in this study. The mean age of the patients was 60.7 $( \pm 11.9)$ years old. Radiotherapy took place over 6 months ago. In all patients the parotid glands were in the field of irradiation. The mean dosage of irradiation on the parotid glands was $29.3( \pm 11.5)$ Gy.

Ten healthy volunteers ( 7 males, 3 females) also participated in this study. Their mean age was $39.8( \pm 12.2)$ years old. They had no known abnormalities in their salivary glands and they did not use any medication affecting salivary flow.

The medical ethical committee of the NKI/AvL hospital was consulted about this study. The medical ethical committee determined that this study was exempt from ethics approval since the study was about the non-invasive collection of a single sample in a small group of patients. All participants gave informed consent.

\section{Saliva collection and storage}

Saliva from the left and right parotid gland was collected using Lashley cups. Salivary flow was stimulated by applying a $4 \%$ citric acid solution to the lateral border of the tongue every $30 \mathrm{~s}$. Saliva was collected during $4 \mathrm{~min}$. After collection a proteinase inhibitor cocktail (PIC; P8340, Sigma, St. Louis, MI, USA) was added to the samples. The samples were frozen immediately in liquid nitrogen and kept at $-80^{\circ} \mathrm{C}$ until analysis.

\section{Saliva handling and analysis}

The saliva samples were analyzed using SELDI-TOF-MS (Bio-Rad, Freemont, USA). Two ProteinChip surfaces were used: the IMAC-30 chip (binds proteins based on metal affinity) and the NP20 chip (general binding of proteins). All chips were loaded according to the manufacturer's instructions (Bio-Rad).

Saliva samples were thawed and centrifuged at $10,000 \mathrm{~g}$ for $5 \mathrm{~min}$. The supernatants were used for analysis. The NP20 chip preparation procedure started with washing of each spot with $5 \mu \mathrm{l}$ PBS. The PBS was removed and $5 \mu \mathrm{l}$ of sample per spot was loaded. The chips were incubated at room temperature for $20 \mathrm{~min}$ under gentle agitation. The chips were washed twice with PBS and air-dried at room temperature for $15 \mathrm{~min}$. Matrix sinapinic acid (50 \% ACN, $0.5 \%$ TFA) was applied twice $(0.8 \mu \mathrm{l}$ each time and $1 \mathrm{~min}$ apart). Finally, the chips were air-dried at room temperature.

The IMAC-30 chip preparation procedure started with loading of $50 \mu \mathrm{l}$ of $0.1 \mathrm{M}$ copper sulphate per spot for $10 \mathrm{~min}$. The spots were washed with $150 \mu \mathrm{l}$ demineralized water. Then the chip surface was neutralized using 
$150 \mu \mathrm{l} 0.1 \mathrm{M}$ sodium acetate buffer at $\mathrm{pH} 4.0$ per spot for $5 \mathrm{~min}$. After washing with $150 \mu \mathrm{l}$ demineralized water the spots were pre-incubated twice with $150 \mu \mathrm{l}$ of binding buffer (0.1 M Tris-HCL, pH 7.4) for 5 min. $1 \mu$ of sample and $99 \mu \mathrm{l}$ of binding buffer per spot were incubated for $1 \mathrm{~h}$ at room temperature under agitation. The spots were washed twice with $150 \mu \mathrm{l}$ binding buffer for $5 \mathrm{~min}$, once with demineralized water and air-dried. Matrix sinapinic acid (50\% ACN, $0.5 \%$ TFA) was applied twice $(0.8 \mu \mathrm{l}$ each time and $1 \mathrm{~min}$ apart) and air-dried.

The externally calibrated chips were read on a ProteinChip Reader IIC instrument (Bio-Rad). The following settings were used: detector voltage $2500 \mathrm{~V}$, acquired mass range from 1 to $30 \mathrm{kDa}$, focus mass $15 \mathrm{kDa}$, matrix attenuation was $1 \mathrm{kDa}$ sampling rate at $400 \mathrm{MHz}, 2$ warning shots were fired at each position, which were not included in the collection, 5 data shots were fired at $2500 \mathrm{~nJ}$.

\section{Protein prediction}

From SELDI-TOF-MS data it is not possible to exactly determine to which (part of) specific proteins and peptides the found peaks correspond as a result of a low mass resolution and a lack of tandem mass spectrometric capabilities, which limits the identification of proteins and peptides [25].

The TagIdent tool (http://web.expasy.org/tagident/) was used to search for proteins that matched the significant SELDI peaks using Swiss-Prot as the database, with human as the organism, with and without the keyword 'secreted'. Searches were carried out using the molecular weight data obtained from the SELDI-TOF-MS analysis with a $1 \%$ molecular weight range.

\section{Statistical analysis}

Peak labeling and statistical analyses of the SELDITOF-MS data were performed with ProteinChip Data Manager Software (version 3.0) for peaks with a signalto-noise ratio of $\geq 3.0$ in the range from 1 to $30 \mathrm{kDa}$. Normalization of the data did not influence overall results. Non-parametric Mann-Whitney tests were performed to compare protein profiles between groups. For the correction of multiple testing, the FDR method was used [32], with a critical value for the false discovery rate of 0.15 and a total number of tests of 435 . That corresponded to a $\mathrm{p}$ value $<0.01$. Other statistical analyses were carried out using the statistical software package SPSS version 18.

\section{Results}

Figure 1 depicts a protein profile of two patients and two healthy controls generated by the IMAC-30 chip. This figure displays amongst others peaks with an $\mathrm{m} / z$ value of
11,748 and 14,720 . These peaks were present in all samples, but they were clearly higher in intensity in the saliva samples of the irradiated patients. Other peaks in this figure were present in all samples and do not differ significantly in intensity between the irradiated patient group and the healthy controls.

On the NP20 chip in total 217 unique peaks were detected. 29 Peaks showed a significant higher intensity and 32 peaks showed a significant lower intensity in the saliva of the irradiated patients (Table 1). All significant peaks are shown in Additional file 1: S1.

On the IMAC-30 chip in total 218 peaks were detected. 23 Peaks showed a significant higher intensity and 9 peaks showed a significant lower intensity in the irradiated patients (Table 2). All significant peaks are shown in Additional file 1: S1.

When comparing the saliva samples from the left and right parotid glands no significant differences were found in peak intensity, neither for the healthy controls, nor for the irradiated patients. The amount of irradiation that the patients received on their left and right parotid glands did not differ significantly $(\mathrm{p}=0.866)$.

The $m / z$ values of all the 93 significantly different peaks were entered in the TagIdent tool and the search resulted in 3528 unique human Swiss-Prot entries. These SwissProt entries were intersected with a list of 917 known salivary proteins and peptides with International Protein Index (IPI) identifiers (20). The IPI identifiers were mapped to Swiss-Prot using the ID-mapping tool of UniProtKB (http://www.uniprot.org). 143 IPI identifiers could not be mapped. The intersection resulted in 186 unique predicted proteins of which 65 are secreted, according to Swiss-Prot. Table 3 lists these 65 predicted proteins of which some have functions that are beneficial to oral health like lysozyme, histatins, proline rich proteins (PRP's) and S100 proteins.

\section{Discussion}

In this study, the rapid and high throughput SELDITOF-MS technique was successfully used to show differences in proteins and peptides in the saliva of irradiated patients compared to healthy controls. The results are in agreement with our hypothesis; many more proteins were found to differ in intensity between the two groups than were studied previously. With this method, it is not only possible to compare protein profiles between groups, but also to rapidly screen patients for a specific protein marker related to (oral) disease and health, to observe the effects of a treatment or preventive measures and to follow composition in time.

Large differences in the composition of parotid saliva between irradiated patients and healthy controls were found: 93 peaks, measured by SELDI-TOF-MS, differed 


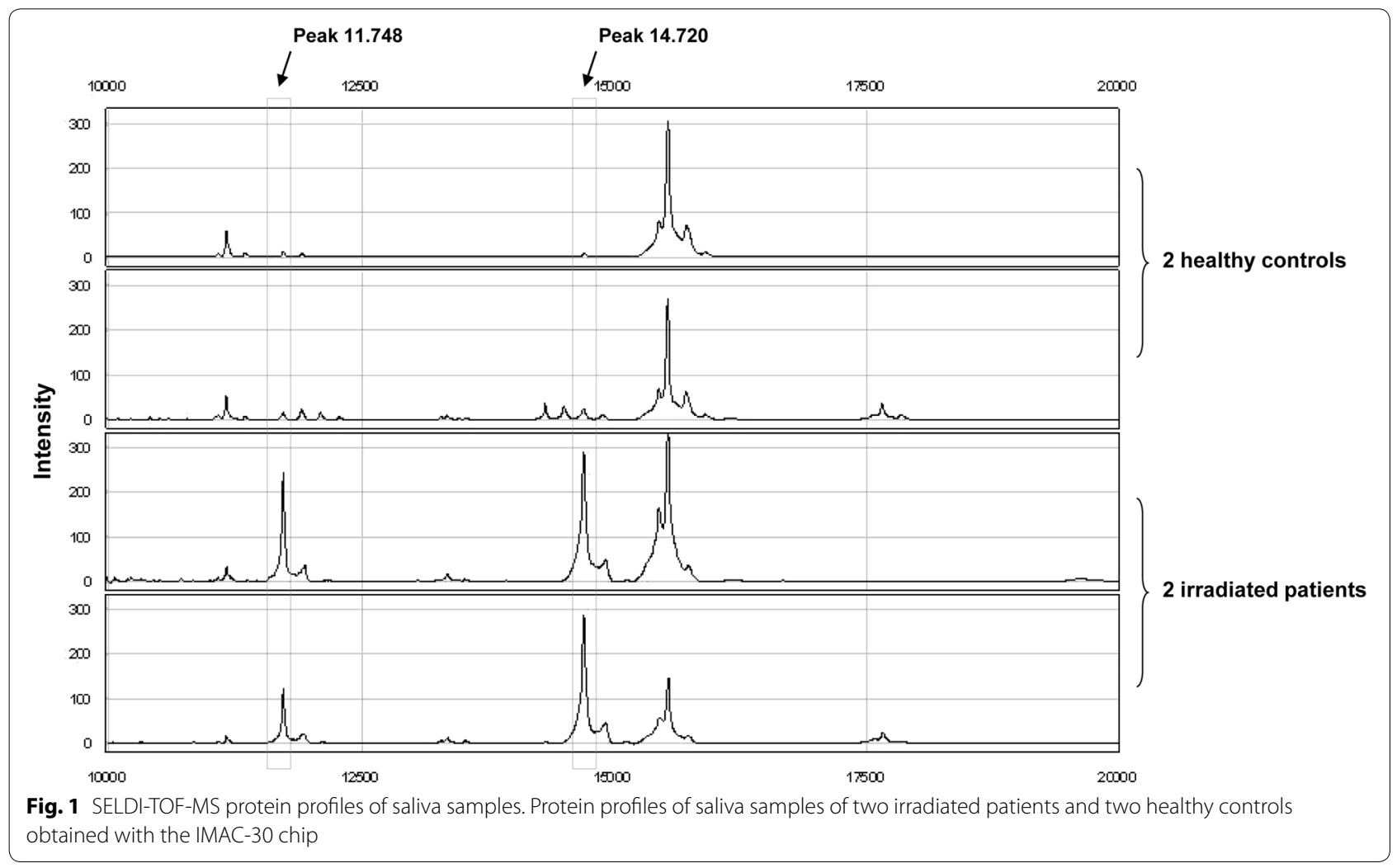

Table 1 Distribution of peaks that differed significantly in intensity on the NP20 chip

\begin{tabular}{llll}
\hline $\boldsymbol{m} / \mathbf{z}$ ratio & $\begin{array}{l}\text { Number } \\
\text { of peaks }\end{array}$ & $\begin{array}{l}\text { Higher in intensity } \\
\text { in patients }\end{array}$ & $\begin{array}{l}\text { Lower in intensity } \\
\text { in patients }\end{array}$ \\
\hline $0-5000$ & 27 & 6 & 21 \\
$5000-10,000$ & 11 & 4 & 7 \\
$10,000-15,000$ & 13 & 10 & 3 \\
$15,000-30,000$ & 10 & 9 & 1 \\
Total & 61 & 29 & 32 \\
\hline
\end{tabular}

Table 2 Distribution of peaks that differed significantly in intensity on the IMAC-30 chip

\begin{tabular}{lccl}
\hline $\boldsymbol{m} / \mathbf{z}$ ratio & $\begin{array}{l}\text { Number } \\
\text { of peaks }\end{array}$ & $\begin{array}{l}\text { Higher in intensity } \\
\text { in patients }\end{array}$ & $\begin{array}{l}\text { Lower in intensity } \\
\text { in patients }\end{array}$ \\
\hline $0-5000$ & 7 & 2 & 5 \\
$5000-10,000$ & 4 & 4 & 0 \\
$10,000-15,000$ & 12 & 10 & 2 \\
$15,000-30,000$ & 9 & 7 & 2 \\
Total & 32 & 23 & 9 \\
\hline
\end{tabular}

significantly in intensity between both groups. Significant peaks can correspond to known proteins and peptides like lysozyme, histatins, PRP's and S100 proteins.
No differences were found in the protein composition of parotid saliva between the left and right parotid gland of both healthy controls and irradiated patients. This is in agreement with a previous study [25].

Until now, most studies were targeted at specific proteins in the saliva between irradiated patients and healthy controls or before and after radiation treatment $[9,10$, $17,33]$. Differences were reported in lysozyme and PRP's concentrations, predicted proteins that are found in our study as well $[10,17,19]$. The interesting point of our study is that we looked at a wide range of proteins and peptides identifying differences that were unnoticed until now. Some of the differences may comprise potential key proteins and peptides in determining oral health.

Other studies with SELDI-TOF-MS found significant differences in peaks between diseased and healthy persons that correspond to our results [26, 28, 31]. Shintani et al. [26] identified a marker for oral squamous cell carcinoma that consisted of truncated cystatin SA. Ryu et al. [28] found several different peaks in Sjögren patients and identified two of the peaks as lysozyme $\mathrm{C}$ and cystatin C. Imanguli et al. [31] studied salivary changes in hematopoietic stem cell transplant patients. They found 78 significantly different peaks comparing pre- and post transplant samples. One peak was identified as cystatin SN. Future studies have to reveal whether various 
Table 3 Secreted proteins and peptides that resulted from the database search

\begin{tabular}{|c|c|}
\hline UniProt accession & Protein name \\
\hline P31947 & 14-3-3 protein sigma \\
\hline P01011 & Alpha-1-antichymotrypsin \\
\hline P03973 & Antileukoproteinase \\
\hline P04280 & Basic salivary proline-rich protein 1 \\
\hline P10163 & Basic salivary proline-rich protein 4 \\
\hline P61769 & Beta-2-microglobulin \\
\hline P13688 & $\begin{array}{l}\text { Carcinoembryonic antigen-related cell adhesion } \\
\text { molecule } 1\end{array}$ \\
\hline P13987 & CD59 glycoprotein \\
\hline P10909 & Clusterin \\
\hline P01034 & Cystatin-C \\
\hline P09228 & Cystatin-SA \\
\hline P01037 & Cystatin-SN \\
\hline P81605 & Dermcidin \\
\hline P19957 & Elafin \\
\hline Q16610 & Extracellular matrix protein 1 \\
\hline P08294 & Extracellular superoxide dismutase $[\mathrm{Cu}-\mathrm{Zn}]$ \\
\hline P02751 & Fibronectin \\
\hline Q8NFU4 & Follicular dendritic cell secreted peptide \\
\hline P47929 & Galectin-7 \\
\hline P28799 & Granulins \\
\hline P00738 & Haptoglobin \\
\hline P15515 & Histatin-1 \\
\hline P15516 & Histatin-3 \\
\hline P01591 & Immunoglobulin J chain \\
\hline P15814 & Immunoglobulin lambda-like polypeptide 1 \\
\hline Q14624 & Inter-alpha-trypsin inhibitor heavy chain $\mathrm{H} 4$ \\
\hline P18510 & Interleukin-1 receptor antagonist protein \\
\hline Q9NZH8 & Interleukin-36 gamma \\
\hline Q9UBX7 & Kallikrein-11 \\
\hline Q9UKR0 & Kallikrein-12 \\
\hline Q92876 & Kallikrein-6 \\
\hline P49862 & Kallikrein-7 \\
\hline P02788 & Lactotransferrin \\
\hline P61626 & Lysozyme C \\
\hline P09237 & Matrilysin \\
\hline Q13421 & Mesothelin \\
\hline O95467 & Neuroendocrine secretory protein 55 \\
\hline P59665 & Neutrophil defensin 1 \\
\hline P80188 & Neutrophil gelatinase-associated lipocalin \\
\hline O75594 & Peptidoglycan recognition protein 1 \\
\hline P00747 & Plasminogen \\
\hline Q16378 & Proline-rich protein 4 \\
\hline O75629 & Protein CREG1 \\
\hline P58499 & Protein FAM3B \\
\hline P31151 & Protein S100-A7 \\
\hline P05109 & Protein S100-A8 \\
\hline P06702 & Protein S100-A9 \\
\hline P00734 & Prothrombin \\
\hline
\end{tabular}

Table 3 continued

\begin{tabular}{ll}
\hline UniProt accession & Protein name \\
\hline P02753 & Retinol-binding protein 4 \\
P07998 & Ribonuclease pancreatic \\
O00584 & Ribonuclease T2 \\
P02810 & Salivary acidic proline-rich phosphoprotein 1/2 \\
P36952 & Serpin B5 \\
Q99954 & Submaxillary gland androgen-regulated protein 3A \\
P02814 & Submaxillary gland androgen-regulated protein 3B \\
P10599 & Thioredoxin \\
O60235 & Transmembrane protease serine 11D \\
P07477 & Trypsin-1 \\
P35030 & Trypsin-3 \\
Q6MZM9 & Uncharacterized protein C4orf40 \\
P11684 & Uteroglobin \\
P04004 & Vitronectin \\
Q6PCB0 & von Willebrand factor A domain-containing protein 1 \\
Q14508 & WAP four-disulfide core domain protein 2 \\
Q96DA0 & Zymogen granule protein 16 homolog B \\
\hline
\end{tabular}

diseases and treatments bring about comparable changes in the salivary protein composition.

We searched for candidate proteins corresponding to the peaks with various protein databases. Among the proteins listed in Table 3 are proteins known to protect oral health, of others the importance is not clear yet. Lysozyme is an enzyme that kills bacteria by breaking down their cell wall. Cystatins are protease-inhibitors that contribute to the prevention of oral infections. The synthesis of cystatins is elevated, when the protective mechanisms in the mouth fail and oral infections originate [34]. Histatins are peptides with an antimicrobial function [35, 36]. Furthermore, histatins exhibit wound healing properties as well [37]. Calprotectin (protein S100A8 and A9) is a zinc- and calcium-binding protein that exhibits antimicrobial activity. It exhibits bacteriostatic properties and is an inflammatory marker in serum [38]. The levels of calprotectin in saliva are higher in the case of oral infections [39]. PRP's are involved in the adherence of bacteria to the enamel pellicle [6]. This study indicates that oral health may be associated with changes in the whole salivary proteome, rather than only a few proteins, Therefore we need to study the whole salivary proteome to find associations and possible mechanisms between these proteins and oral health.

The mean age of the patients in our study was higher than of the healthy controls, due to one older patient. The changes in protein composition due to age are minimal and usually related to age-related medical conditions, as in our study [40]. In addition, by correcting the $\mathrm{p}$ value 
for multiple testing, we only found large differences in the relative abundance of proteins in parotid saliva. Therefore, these differences have to be related to the impaired health condition and not to age differences.

The specific cause of the changes in protein composition that we found is not clear. It is possible that the disease itself altered the composition of saliva, but it can also be the (amount of) irradiation that caused the changes. To distinguish between these possible options, it is necessary to compare the salivary protein composition of the cancer patients before and after radiotherapy.

In conclusion, many differences are found in the protein and peptide composition of parotid saliva of patients irradiated in the head and neck area compared to healthy controls. Of some proteins the relation with oral health is known, for others it remains to be established. It is important to look at a broad range of proteins to identify associations between changes in the salivary proteome and health or disease that were unnoticed until now. Further research is needed to prospectively study changes in salivary proteins and to relate those changes to oral health.

\section{Additional file}

Additional file 1: S1. All significant peaks ( $\mathrm{m} / \mathrm{z}$ ratio) with corresponding p-values.

\section{Authors' contributions}

$A M L, C R$ and $C L$ designed the study. AML and CR collected the data. AML, $\mathrm{BB}, J \mathrm{~S}, \mathrm{RS}, \mathrm{AL}$ and ES analyzed and interpreted the data. All authors read and approved the final manuscript.

\begin{abstract}
Author details
${ }_{1}^{1}$ Department of Preventive Dentistry, Academic Centre for Dentistry Amsterdam, University of Amsterdam and VU University Amsterdam, Gustav Mahlerlaan 3004, 1081 LA Amsterdam, The Netherlands. ${ }^{2}$ Department of Radiation Oncology, The Netherlands Cancer Institute, Antoni van Leeuwenhoek Hospital, Plesmanlaan 121, 1066 CX Amsterdam, The Netherlands. ${ }^{3}$ Top Institute Food and Nutrition, PO Box 557, 6700 AN Wageningen, The Netherlands. ${ }^{4}$ Central Laboratory for Haematology, Radboud University Nijmegen Medical Centre Post 476, PO Box 9101, 6500 HB Nijmegen, The Netherlands. ${ }^{5}$ NIZO Food Research B.V., P.O. Box 20, 6710 BA Ede, The Netherlands.
\end{abstract}

\section{Acknowledgements}

None of the researchers received funding from external sources.

\section{Competing interests}

The authors declare that they have no competing interests.

Received: 28 July 2014 Accepted: 27 October 2015

Published online: 03 November 2015

\section{References}

1. Vissink A, Jansma J, Spijkervet FK, Burlage FR, Coppes RP. Oral sequelae of head and neck radiotherapy. Crit Rev Oral Biol Med. 2003;14:199-212.

2. Fujita M, Tanimoto K, Wada T. Early radiographic changes in radiation bone injury. Oral Surg Oral Med Oral Pathol. 1986;61:641-4.
3. Randall K, Stevens J, Yepes JF, Randall ME, Kudrimoti M, Feddock J, Xi J, Kryscio RJ, Miller CS. Analysis of factors influencing the development of xerostomia during intensity-modulated radiotherapy. Oral Surg Oral Med Oral Pathol Oral Radiol. 2013;115:772-9.

4. Burlage FR, Coppes RP, Meertens H, Stokman MA, Vissink A. Parotid and submandibular/sublingual salivary flow during high dose radiotherapy. Radiother Oncol. 2001;61:271-4.

5. Braam PM, Roesink JM, Raaijmakers CP, Busschers WB, Terhaard CH. Quality of life and salivary output in patients with head-and-neck cancer five years after radiotherapy. Radiat Oncol. 2007;2:3.

6. Van Nieuw Amerongen A, Bolscher JG, Veerman EC. Salivary proteins: protective and diagnostic value in cariology? Caries Res. 2004;38:247-53.

7. Baker OJ, Edgerton M, Kramer JM, RuhI S. Saliva-microbe interactions and salivary gland dysfunction. Adv Dent Res. 2014;26:7-14.

8. Aguiar GP, Jham BC, Magalhaes CS, Sensi LG, Freire AR. A review of the biological and clinical aspects of radiation caries. J Contemp Dent Pract. 2009;10:83-9.

9. Almstahl A, Wikstrom M, Groenink J. Lactoferrin, amylase and mucin MUC5B and their relation to the oral microflora in hyposalivation of different origins. Oral Microbiol Immunol. 2001;16:345-52.

10. Brown LR, Dreizen S, Rider LJ, Johnston DA. The effect of radiationinduced xerostomia on saliva and serum lysozyme and immunoglobulin levels. Oral Surg Oral Med Oral Pathol. 1976;41:83-92.

11. Funegard U, Franzen L, Ericson T, Henriksson R. Parotid saliva composition during and after irradiation of head and neck cancer. Eur J Cancer B Oral Oncol. 1994;30B:230-3.

12. Valdez IH, Atkinson JC, Ship JA, Fox PC. Major salivary gland function in patients with radiation-induced xerostomia: flow rates and sialochemistry. Int J Radiat Oncol Biol Phys. 1993;25:41-7.

13. Almstahl A, Wikstrom M. Oral microflora in subjects with reduced salivary secretion. J Dent Res. 1999;78:1410-6.

14. Almstahl A, Wikstrom M, Fagerberg-Mohlin B. Microflora in oral ecosystems in subjects with radiation-induced hyposalivation. Oral Dis. 2008;14:541-9.

15. Epstein JB, Chin EA, Jacobson JJ, Rishiraj B, Le N. The relationships among fluoride, cariogenic oral flora, and salivary flow rate during radiation therapy. Oral Surg Oral Med Oral Pathol Oral Radiol Endod. 1998;86:286-92.

16. Keene HJ, Fleming TJ. Prevalence of caries-associated microflora after radiotherapy in patients with cancer of the head and neck. Oral Surg Oral Med Oral Pathol. 1987:64:421-6.

17. Hannig M, Dounis E, Henning T, Apitz N, Stosser L. Does irradiation affect the protein composition of saliva? Clin Oral Investig. 2006;10:61-5.

18. Christensen ME, Hansen HS, Poulsen SS, Bretlau P, Nexo E. Immunohistochemical and quantitative changes in salivary EGF, amylase and haptocorrin following radiotherapy for oral cancer. Acta Otolaryngol. 1996;116:137-43.

19. Dijkema T, Terhaard CH, Roesink JM, Raaijmakers CP, van den Keijbus PA, Brand HS, Veerman EC. MUC5B levels in submandibular gland saliva of patients treated with radiotherapy for head-and-neck cancer: a pilot study. Radiat Oncol. 2012;7:91.

20. Makkonen TA, Tenovuo J, Vilja P, Heimdahl A. Changes in the protein composition of whole saliva during radiotherapy in patients with oral or pharyngeal cancer. Oral Surg Oral Med Oral Pathol. 1986;62:270-5.

21. Almstahl A, Wikstrom M. Electrolytes in stimulated whole saliva in individuals with hyposalivation of different origins. Arch Oral Biol. 2003;48:337-44

22. Denny P, Hagen FK, Hardt M, Liao L, Yan W, Arellanno M, Bassilian S, Bedi GS, Boontheung P, Cociorva D, et al. The proteomes of human parotid and submandibular/sublingual gland salivas collected as the ductal secretions. J Proteome Res. 2008;7:1994-2006.

23. Schipper R, Loof A, de Groot J, Harthoorn L, van Heerde W, Dransfield E. Salivary protein/peptide profiling with SELDI-TOF-MS. Ann NY Acad Sci. 2007;1098:498-503.

24. Al-Tarawneh SK, Bencharit S. Applications of surface-enhanced laser desorption/ionization time-of-flight (SELDI-TOF) mass spectrometry in defining salivary proteomic profiles. Open Dent J. 2009;3:74-9.

25. Schipper R, Loof A, de Groot J, Harthoorn L, Dransfield E, van Heerde W. SELDI-TOF-MS of saliva: methodology and pre-treatment effects. J Chromatogr B Analyt Technol Biomed Life Sci. 2007;847:45-53.

26. Shintani S, Hamakawa H, Ueyama Y, Hatori M, Toyoshima T. Identification of a truncated cystatin SA-I as a saliva biomarker for oral squamous cell 
carcinoma using the SELDI ProteinChip platform. Int J Oral Maxillofac Surg. 2010;39:68-74.

27. Streckfus $C F$, Bigler $L R$, Zwick M. The use of surface-enhanced laser desorption/ionization time-of-flight mass spectrometry to detect putative breast cancer markers in saliva: a feasibility study. J Oral Pathol Med. 2006;35:292-300

28. Ryu OH, Atkinson JC, Hoehn GT, Illei GG, Hart TC. Identification of parotid salivary biomarkers in Sjogren's syndrome by surface-enhanced laser desorption/ionization time-of-flight mass spectrometry and twodimensional difference gel electrophoresis. Rheumatology (Oxford). 2006:45:1077-86

29. Gallo A, Martini D, Sernissi F, Giacomelli C, Pepe P, Rossi C, Riveros P, Mosca M, Alevizos I, Baldini C. Gross cystic disease fluid protein-15(GCDFP-15)/ prolactin-inducible protein (PIP) as functional salivary biomarker for primary sjogren's syndrome. J Genetic Syndrome Gene Therapy 2013;4:140. doi:10.4172/2157-7412.1000140

30. Range H, Leger T, Huchon C, Ciangura C, Diallo D, Poitou C, Meilhac O, Bouchard P, Chaussain C. Salivary proteome modifications associated with periodontitis in obese patients. J Clin Periodontol. 2012;39:799-806.

31. Imanguli MM, Atkinson JC, Harvey KE, Hoehn GT, Ryu OH, Wu T, Kingman A, Barrett AJ, Bishop MR, Childs RW, et al. Changes in salivary proteome following allogeneic hematopoietic stem cell transplantation. Exp Hematol. 2007;35:184-92.

32. Benjamini $Y$, Hochberg $Y$. Controlling the false discovery rate: a practical and powerful approach to multiple testing. J Roy Stat Soc Ser B (Methodol). 1995;57:289-300
33. Vidotto A, Henrique T, Raposo LS, Maniglia JV, Tajara EH. Salivary and serum proteomics in head and neck carcinomas: before and after surgery and radiotherapy. Cancer Biomark. 2010;8:95-107.

34. Henskens YM, Veerman EC, Mantel MS, van der Velden U, Nieuw Amerongen AV. Cystatins $S$ and $C$ in human whole saliva and in glandular salivas in periodontal health and disease. J Dent Res. 1994;73:1606-14.

35. Yamagishi H, Fitzgerald DH, Sein T, Walsh TJ, O'Connell BC. Saliva affects the antifungal activity of exogenously added histatin 3 towards Candida albicans. FEMS Microbiol Lett. 2005;244:207-12.

36. Sugimoto J, Kanehira T, Mizugai H, Chiba I, Morita M. Relationship between salivary histatin 5 levels and Candida CFU counts in healthy elderly. Gerodontology. 2006;23:164-9.

37. Oudhoff MJ, Bolscher JG, Nazmi K, Kalay H, van't Hof W, Amerongen $A V$, Veerman EC. Histatins are the major wound-closure stimulating factors in human saliva as identified in a cell culture assay. FASEB J. 2008;22:3805-12.

38. Striz I, Trebichavsky I. Calprotectin - a pleiotropic molecule in acute and chronic inflammation. Physiol Res. 2004;53:245-53.

39. Sweet SP, Denbury AN, Challacombe SJ. Salivary calprotectin levels are raised in patients with oral candidiasis or Sjogren's syndrome but decreased by HIV infection. Oral Microbiol Immunol. 2001;16:119-23.

40. Dodds MW, Johnson DA, Yeh CK. Health benefits of saliva: a review. J Dent. 2005;33:223-33.

\section{Submit your next manuscript to BioMed Central and take full advantage of:}

- Convenient online submission

- Thorough peer review

- No space constraints or color figure charges

- Immediate publication on acceptance

- Inclusion in PubMed, CAS, Scopus and Google Scholar

- Research which is freely available for redistribution

Submit your manuscript at 